\title{
Vuosi jota ei koskaan tullut?
}

Kuluvaa vuotta 1984 on kutsuttu Orwellin vuodeksi. Nimitys johtuu englantilaisen kirjailijan George Orwellin vuonna 1949 julkaistusta romaanista "Vuonna 1984"'. Kyseistä kirjaa on pidetty eräänä kaikkien aikojen huomattavimpana ja eniten ihmisten tulevaisuudenkuvitelmiin vaikuttaneena teoksena. Vaikka kysymys on kaunokirjallisesta teoksesta, niin monilla tahoilla on seurattu huolestuneina Orwellin 'ennusteiden"' toteutumista. Myöskin suomalaisissa sanoma- ja aikakauslehdissä on ollut tänä vuonna jo useita artikkeleita, joissa on pyritty osoittamaan, miten oikeaan Orwellin pessimistiset ennustukset yhteiskunnan kehityksestä kohti totalitarismia ovat osuneet.

Futuristit eivät tietysti olisi futuristeja, jolleivat he pyrkisi olemaan aikaansa edellä. Niinpä "'The Futurist'" -aikakauslehti käsitteli Orwellin kirjaa jo viime vuoden viimeisessä rumerossa. Asiantuntijoiden artikkeleissa pyrittiin analysoimaan $\mathrm{mm}$. sitä, onko romaania tarkasteltava tulevaisuuden ennusteena "'profetiana" vaiko varoituksena siitä, mihin suuntaan yhteiskuntakehitys on kulkemassa, jos siihen ei puututa. Kirjoittajat ovat yksimielisiä siitä, että kysymys on oikeastaan oman ajankohtansa, eli toisen maailmansodan jälkeisiä vuosia käsittelevästä satiirista. Kirjan pessimismi oli kuitenkin sitä luokkaa, että kustantaja halusi siirtää näkökulman kauemmaksi tulevaisuuteen. Kirjan kirjoittamisvuoden kaksi viimeistä numeroa kääntämällä saatiin vuosi 1984. Näin alunperin oman ajankohdan satiiriksi tarkoitetusta kirjasta tulikin tulevaisuudenennuste, joka on herättänyt keskustelua ympäri maailman. On paljon pohdittu sitä, onko tämä yhden miehen pessimistinen maailmankuva muuttunut koko maailmaa käsittäväksi todellisuudeksi. Jostain syystä pessimismi ''myy'” tällä hetkellä paremmin kuin optimismi. Tämä näkyy mm. siinä, että viime aikoina ei juurikaan ole esitetty positiivisia utopioita, korkeintaan "eloonjäämisoppeja'.

The Futurist -lehden asiantuntijat ovat kuitenkin sitä mieltä, että Orwellin vuosi 1984 on vuosi, jota ei koskaan tullut. Vaikka hänen kuvailemansa teknologinen kehitys onkin suurin piirtein toteutunut, niin hänen käsityksensä länsimaisen yhteiskuntaelämän sortumisesta täydelliseen totalitarismiin, ilman kansalaisille kuuluvia demokraattisia oikeuksia ja vailla mielipiteen sekä sananvapautta, ei ole onneksi toteutunut. Samoin hänen ennustuksensa 1950-luvulla tapahtuvasta atomisodasta, väestön enemmistön elinolosuhteiden kurjistumisesta ja moraalisen suvaitsemattomuuden leviämisestä ovat osoittautuneet vääriksi. Sensijaan hänen näkemyksensä tietynlaisesta "'holhousyhteiskunnasta"' ja yhteiskunnan jäsenten jatkuvasta valvonnasta näyttävät olevan ainakin osittain toteutumassa. Nämä kehitystrendit on kuitenkin tiedostettu ja ongelmiin ollaan etsimässä ratkaisua. Tärkeimmiltä osiltaan yhteiskunnallinen kehitys on siis ollut lähes päinvastainen, kuin mitä Orwell esitti. Jos olemme rehellisiä, niin meidän suomalaisten on tunnustettava, että elämme ilmeisesti maamme historian rauhallisinta, vaurainta ja poliittisesti vapainta aikaa. Edellä sanotulla en tietysti- 
kään halua mitenkään mitätöidä Orwellin kirjan arvoa, päinvastoin. Ilmeisesti se on omalta osaltaan ollut vaikuttamassa siihen, etteivät nämä ennusteet ole toteutuneet.

Vaikka tällä hetkellä elämmekin aikaa, jolloin vanhat aatteet eivät enää oikein lämmitä eivätkä uudet ole vielä päässeet puhkeamaan kukkaan, niin siitä huolimatta on mielestäni monestakin syystä aihetta optimismiin. Jatkuvan kasvun ideologiaan ja teknokraattiseen yhteiskuntasuunnitteluun on alettu suhtautua yhä kriittisemmin, jopa suunnittelijoiden omassa piirissä. Muutenkin ihmisläheisyys ja pehmeät arvot ovat suosiossa. Eräs tärkeä seikka on myös se, että olemme alkaneet tajuta, ettemme voi elää kuin pellossa välittämättä lähiympäristömme hyvinvoinnista ja siitä, mitä muualia maailmassa tapahtuu. Työn väheneminen ja sen luonteen muuttuminen ovat pakottaneet meitä pohtimaan ihmisen perustarpeita aivan uudella tavalla. - Jo edellä esitetyt hajahuomiot osoittavat sen, että emme elä missään pysähtyneessä tilassa, vaan keskellä voimakasta uutta kehityskautta. Se ei ole niinkään määrällisiin kuin laadullisiin tavoitteisiin pyrkivä. Tässä tilanteessa syntyy runsain mitoin uusia haasteita, jotka aikuiskasvatuksessakin täytyy uskaltaa ottaa vastaan. Ne on tietysti jo pyrittykin ottamaan monilla tahoilla huomioon opetussuunnitelmia laadittaessa, kuitenkin tehtävää on edelleen paljon. Aikuiskasvatuksen on tarjottava nykypäivän aikuisille riittävät tiedolliset ja muut resurssit, jotta he voisivat ottaa nämä haasteet vastaan omiin kykyihinsä luottaen. Koska elämme yhä tieteellistyvämmässä maailmassa, niin tämä edellyttää tieteellisen yleissivistävän koulutuksen tarjoamista kaikille. Tästä syystä professori Harvan ja Kontiaisen artikkeleissaan esittämiin ajatuksiin aikuisten tietotason kohottamisesta uudelle, tieteelliselle tasolle täytyy suhtautua mitä vakavammin. Olisi pohdittava sitä, minkälainen tulisi olla tämän päivän ja tulevaisuuden aikuisten tieteellinen yleissivistys sekä sitä, miten sen välittäminen mahdollisimman laajoille kansalaispiireille voisi käytännössä tapahtua.

Aikuiskasvatuksellisti tämä vuosi on merkittävä, sillä onhan Aikuiskoulutuksen kehittämisorganisaation ensimmäinen työvaihe nyt saatettu pääosiltaan loppuun. Nyt on esitysten ja toimikuntien raporttien arvioinnin aika. Niihin toivoisi lukijoilta mahdollisimman paljon kommentteja. Aikuiskasvatus -lehti tarjoaa sivunsa kaikkien käytettäväksi. Mieluimmin otetaan vastaan lyhyehköjä kannanottoja periaatteellisesti keskeisiin kysymyksiin. Laajat yleisesityksetkin ovat tervetulleita, mutta niitä saatetaan joutua karsimaan. Kaikki otetaan kuitenkin mielihyvin vastaan.

Aikuiskasvatuksen "kokonaisuudistus"' on jälleen näköetäisyydellä tulevaisuudessa, vai onko? Toivottavasti sille ei käy kuten Orwellin vuodelle. 